Intermedia International e-Journal, Spring -June - 2016 3(1)

\title{
DYSTOPIAN TUNES: ROLE OF MUSIC IN CREATING ATMOSPHERE WITHIN THE CONTEXT OF “REPO! THE GENETIC OPERA”
}

\section{Distopik Ezgiler: "Repo! The Genetic Opera" Çerçevesinde Müziğin Atmosfer Yaratmadaki Rolü}

\author{
Research Assistant Volkan EROL ${ }^{1}$, Assoc. Prof. Gülin TEREK ÜNAL ${ }^{2}$, Dila Naz MADENOĞLU ${ }^{3}$, \\ Istanbul University, Faculty of Communication, \\ Istanbul
}

\begin{abstract}
Music has always been an indispensable element of cinema since the silent movie era. Yet with the advent of sound, music became a part of the movie as a defining element. Sound effects and music are being used in horror and science fiction genres in order to emotively affect the spectator and bring them into the world that is created in the movie; and are as important as the visual setting and narrative structure. Dystopian science fiction movies, which are a subgenre of the science-fiction genre, depict a dark future and use music to support this depiction. Generally, rock and metal music are utilized in these kinds of movies because the critical words of songs and heavily distorted electric guitars suit well the environs depicted in dystopic science fiction. In this paper, the musical "Repo! The Genetic Opera" (Daren Lynn Boussman, 2008) will be examined and how the dystopic atmosphere of the movie fits to its music; and how the music plays an essential role in creating this atmosphere will be studied. Combining the slasher subgenre with dystopic science fiction and linking it to the musical and the gaining of a cult following in a short amount of time is the reason why the movie is chosen.
\end{abstract}

Key Words: dystopia, horror, music, rock opera, cinema

Özet Müzik, sinemanın her zaman vazgeçilmez bir öğesi olmuştur. Sessiz sinema döneminde, filmin ritmine göre canlı çalınan müzikler oldukça ön planda iken, sese geçişle beraber zamanla tamamlayıcı bir unsura dönüşmüş, film eleştirilerinde ve çözümlemelerinde ele alınacak kodlardan biri haline gelmiştir. Özellikle, korku, bilimkurgu gibi film türlerinde izleyiciyi etkilemek ve yaratılan dünyanın içine sürüklemek amacıyla kullanılan ses efektleri ve müzikler, hem üretim aşamasında, hem de eleştiri ve çözümlemelerde, en az anlatı yapısı ve görsel düzenlemeleri kadar, üzerinde durulan noktalar olmuşlardır. Bilimkurgu sinemasının alt türlerinden biri olan distopik bilim kurgu filmleri, karanlık bir gelecek tasvir etmekte ve bu tasviri destekleyecek müzikler kullanmaktadır. Rock ve metal müzik, gerek eleştirel sözleri gerekse aşırı derecede distortion kullanılmış elektro gitara dayanan sert yapısıyla, distopik filmlerin tercih ettiği türlerden biridir. Bu çalışmada Daren Lynn Boussman'ın yönettiği 2008 yapımı "Repo the Genetic Opera" adlı müzikal filmde kullanılan müziklerin filmin distopik atmosferiyle uyumu ve atmosfer yaratmada oynadığı roller, "rock opera" olarak tanımlanan müzik türü kapsamında incelenecektir. Slasher alt türünün kimi öğelerini distopik bilimkurgu ile birleştirerek müzikal ile harmanlaması ve kısa zamanda kült bir izleyici kitlesine sahip olması filmin seçilme nedenini oluşturmaktadır.

\footnotetext{
${ }^{1}$ volkan.erol@istanbul.edu.tr

2 gterek@istanbul.edu.tr

3 dilanazmadenoglu@gmail.com
} 
Genel tarama modelinin kullanılacağı çalışmada, yöntem olarak göstergebilimsel çözümlemeden de yararlanılacaktır.

Anahtar Kelimeler: distopya, korku, müzik, rock opera, sinema

\section{Introduction}

Cinema combines the characteristics of different art forms, forging them together into one medium and creating a new artform that is considered as the seventh art. Elements from literature, painting, music, theatre and so on, all play important roles in defining what is cinema. Some of the elements appeal to the eyes, whilst others appeal to the ears in the attempt to create an audio and visual experience. In this sense, the role of the music and sound cannot be underestimated when it comes to defining the meaning of a scene or that of the whole movie. The sound or the music can be placed as a diegetic or non-diegetic sound; both having an important function. Of the many studies focusing on the usage of music in cinema, most under-debate the function of music, relegating it to simple analysis of a single frame in the movies that are examined. Beyond this, when it comes to studying the elements that are needed in order to create the atmosphere, there are no sufficient studies on the effect of music as it is expected to enhance the atmposhere being generated.

Music usage does vary from genre to genre, and it can be said that some music types fit better with some genres than they do with others. Certainly, all genres of music and cinema have their own characteristics; and thus that it is important for the genres that are used together mesh well in order to create a meaningful whole. For some genres, such as musicals, both the visual arrangements and music usage are feed from each other. Although the genre characteristics may change from theatrical musicals to musical movies, the inherent importance of music's role remains the identical. The characteristics of the musical genre could unite with other movie genres and create a new sub-genre; for instance, in the movie Repo! The Genetic Opera is a subgenre that unifies rock with opera and musicals with the science-fiction genres. This movie has its own characteristics both musically and visually.

This movie is a typical example of the cyberpunk brand, incorporating all the characteristics of its genre. The main reason for selecting this film is that it also allows for examination of the concept of heterotopia in the depiction of a dystopian future. At the same time, it is observed that the musical elements exude overtones of the pessimistic structure, cultural and physical degeneration visually imparted by this film. Usually the musical expresses a utopian ideal and has a positive contribution to the atmosphere being constructed. Creating a conflict over the characteristics of the opera and its purpose and converting a musical form under the auspices of the elite into a dystopian universe construction is noteable. Although it is known that opera belongs to a certain coterie, rock's connotation to anarchy and subversiveness prepares the groundwork for a critical point of view.

In conducting this study, in order to analyze the visuals in the movie, a semiotic approach has been adopted. In addition, the music and the songs in the movie, alongside the lyrics and dialogues will be examined for their content and structure vis-a-vis the effect that they have.

\section{Rock Opera and Characteristics of Dystopian Science Fiction}

Although there is no literally accurate information about how and when the first music-like works came out, there is some evidence that prove the history of music dates back to prehistoric times.

According to McClellan, the earliest physical evidence of music activity that they possess, a clay ocarina with five holes, bespeaks an already flourishing use of music as early as 10.000 B.C. (2000:1). 
As time progressed, the practices of creating music, the tools used to make music or the form of the music were seen to diverge from culture to culture. Music types, belonging to some cultures or subcultures, were one of the reasons that music genres became prevalent. Music genres categorize and organize the musical materials, thus each category has their own way of creating music.

Pop, R\&B, Jazz, Rock'n Roll, Metal, Country, Reggae, Tango are some of the main genres of music; however there are roughly 60 genres and also variegated subgenres under these (Lena, Peterson, 2008:701).

Some formations that occurred are a fusion of several different art forms, such as revues, musicals and operas.

Fisher defined opera, as a form which embraces the entire spectrum of theatrical elements: dialogue, acting, costumes, scenery and action; it is the sum total of all these elements, as the combining of silence, words and music, that is a formal theatrical medium that expresses its dramatic essence by integrating its words and action with music (2005:14). Musicals, on the other hand, are formed with similar elements to opera such as dialogue, acting, costumes, scenery, action and of course music. However, whilst musicals have spoken dialogues (Çedikçi, 2008:38), operas don't. Operas are Euro-centric, whereas musicals are a birth-right of the U.S.A. The history of operas goes back to the $16^{\text {th }}$ century; on the other hand musicals are mainly creations of the late $19^{\text {th }}$ century (ilyasoğlu, 2009:47,263).

Opera is based on two art forms, music and theatre. Opera neither superimposes these art forms, nor conglutinates them. Opera is the combination of theatre and music that rejoices in literature, poetry and plastic arts (Say, 1997:165). The first opera piece in the history is Dafne by Ottavio Rinuccini and Jecopo Peri in 1598 (Sonneck, 1913:102). Opera spread from Italy to become a global phenomenon and has continued to influence cultures and been influenced by them. In each era, opera pieces developed and oriented to reflect that era's conditions. From baroque to classic period, romantic to modern period, opera continued to be an ongoing mirror of society.

When it comes to the $20^{\text {th }}$ century, it is seen that opera is combined with some other music genres such as rock, rap (hip-hopera) or pop (operatic pop/popera). However, these subgenres are appurtenant to rock, rap or pop genres, not the opera genre. These combinations, became an amalgam almost anathema with the form of opera because it was neither traditional nor high culture anymore. The reason that opera was considered as a high culture type of art is because, in order to watch an opera at opera houses in the $17^{\text {th }}$ century, people needed to purchase tickets. That way, opera turned into an entertainment that is suitable for the ones who could afford the tickets, the wealthy people who are willing and able to pay for entertainment. Buildings that are specially made for operas, codes of behavior, dress codes and foreign language operas, turned the opera into snobbish club for the elite. This situation kept going until the $19^{\text {th }}$ century, when opera became a popular entertainment consumed by people from all social classes. (Storey, 2002:33,34).

Turning into a popular entertainment form let opera coalesce with other genres of music, such as rock opera, as stated before. According to Elicker, what separates the traditional opera from the rock opera is, rock operas are usually performed by the composers/musicians themselves (2002:300). Rock opera composition is a bringing together of rock, classical, vaudeville, choral and electronic pieces (Nassour, Broderick, 1973:61). Rock operas also qualify as operas, as they center around human beings and their conflicts and problems and deal with these aspects in a coherent and cohesive way unlike rock music. Unlike musicals, rock operas seem to be a purely British phenomenon simply because England was not successful at musical theatre, therefore they came up with a new type of musical theory: rock 
opera. The first product of the rock opera is Tommy, by the British rock band The Who, in 1969 (Elicker, 2002:300-301). After Tommy, rock opera was recognized and more pieces were being produced.

"They reached its peak in the late 1960s and early 1970s in England - at a time when rock and pop musicians were keen on experimenting with new musical forms and contents, and when society in Europe was, after the highly active 1960s in the United States, still very much interested in musical treatments of contemporary problems and hardships. The Who's rock opera follow-up to Tommy, Quadrophenia, was released in 1973; from 1969 to 1975, another British rock band, the Kinks, released four rock operas: Arthur or the Decline and Fall of the British Empire (1969), Preservation (1973), Soap Opera (1975), and Schoolboys in Disgrace (1975). JethroTull's front man lan Anderson also experimented with the rock opera format in the 1970s, contributing 1972's Thick as a Brick, 1973's A Passion Play, and 1976's Too Old to Rock'n'Roll: Too Young to Die." (Elicker, 2002:302)

With improvement of the cinema industry, music started to play more significant roles in movies. The movie musical was born in the late 1920's hence, was a comparative latecomer to film genres (Barrios, 1995:3,4). Most of the critics cite The Jazz Singer (1927) as the first screen musical and at the height of the studio era; any film with three or more songs was considered a musical (Parkinson, 2007, vi)."In the late 1950s and 1960s, musical films, now largely made for a younger, segmented market, reflected the growth in importance of the popular music industry and attempted to exploit the success of popular music recording artists." (Mundy, 2006:42). There are some subgenres of musical films such as musical comedy or musical drama, which drive musical films to create their own mass.

Opera films are a genre that is generated by opera music and built entirely on it (Citron, 2010:75). In the 1970's and 1980's, a significant increase in the number of films that utilize opera can be observed, perhaps for metaphorical purposes. Opera may work on the metaphorical axis of thought, so the concept of the opera film involves the clashing of two codes, metaphoric and metonymic (Tambling, $1987: 50,163)$. Only rarely is the mortal rock opera that does well on the theatrical stage accepted into eternal celluloid heaven. This was the case with the film version of Tommy (1975) directed by Ken Russell as well as that of Pink Floyd's The Wall (1982) directed by Alan Parker. Many screenings of rock opera style productions have integrated the audience into the production. The Rocky Horror Picture Show is the most well known of these productions. One can also look at the promotional screenings and tour that was done for the film Repo the Genetic Opera in 2008. During the tour, different members of the cast would be present at the screenings to answer questions and perform signature lines, such as the Graverobber's "Graaaaavvvesees" for the audience at the designated moments in the film, if requested. In some cases the audience is acknowledged, such as in Repo's Graverobber's "21st Century Cure," but the audience rarely has any ability to respond. The exception can be found in larger cult screenings where arguably the audience can change a character through their interaction. In these cases, even when the performer is not present, there is some form of audience and performer interaction (Grossman, 2012:42,43).

Musicals and operas are already combinations of some art forms, which are music, theatre, drama and literature; yet musical films or opera films incorporate with cinema too. Hereby, not only the cinema earns a new genre, opera and musicals get to meet with more people too.

In the case of horror and science fiction cinema, music and sound design have a different importance. 
"Music and sound effects, particularly ambient effects, in horror films present a dark lyricism shaped by the need for a spectacle of intensity or excess, dark emotions, and atmosphere. Orchestrations in minor keys, thunder rumbles and guttural growls can foreshadow a descent into unfamiliar territory or accentuate psychological fracture or weakness within characters. The expressionist results are chilling to filmgoers as the music and sounds of the night rake up and down their spines. The genre contract regarding horror films often stresses visceral impact over narrative causality and unity... In short, the horror film is more often meant to frighten rather than enlighten, though some of them have managed to achieve both of these intents. " (Whittington, $2007: 131$ )

This statement also holds true for dystopian science fiction movies, since they need to reflect the horrors of the bleak, dark, hopeless future they create; dystopias like Orwell's 1984 which is a "terrifying evocation of our collective fears, our cultural delirium." (Reilly,1989:20) "Because people have always feared being slaves to technology--that some day machines, or governments, megacorporations which control the technology, will control our lives, takeover our humanity, and define our reality." (Harris,2003:77)

Dystopian works, have some characteristic elements:

“(1) A hierarchical society where divisions between the upper, middle and lower classes are definitive and unbreakable (Caste system).

(2)The propaganda and educational system have the purpose of preserving the Caste system.

(3)The cancellation of individuality.

(4)The presence of symbols presented as commandments of a religious faith, that at the same time summarize and hide the aims of the state.

(5)The constant surveillance by state police agencies.

(6)Backstory of a disaster that justifies the dramatic social changes.

(7)A protagonist that doubts the society.

(8)More advanced technologies." (Mahida, 2011.:2 )

Cyberpunk, which is a subgenre of science fiction, shares these characteristic with dystopias, since it also represents dystopian futures.

"Dystopian narratives are also important precursors of cyberpunk. Bernard Wolfe's Limbo (1952), for instance, foreshadows cyberpunk in its depiction of a North America emerging from nuclear destruction, in which invasive technologies of the body, including lobotomy, play a significant part. The theme of body transformation - bound to become central to cyberpunk in its treatment of biotechnology -also features prominently in Alfred Bester's The Stars My Destination (1955). This novel also heralds cyberpunk through its anarchic emphasis on the collapse of intelligible boundaries between acceptable and criminal forms of conduct. "(Cavallaro,2001:9)

Depictions of a future that cyberpunk represents contains high-tech, magnificent, sparkling cities with skyscrapers, colorful, everchanging and almost kaleidoscopic advertisements on giant screens that surround people and bombarding them with images; also in contrast, bummers, junkies, criminals, street dealers and dark streets that are a shelter for people who just try to survive in these chaotic, high-tech cities.

William Gibson is considered one of the most influential authors of cyberpunk. His novels, especially 
Neuromancer (1984), have been a source of inspiration for cult movies from Ghost in the Shell (Mamoru Oshii, 1995) to The Matrix (Wachowski Brothers, 1999).

"Gibson's works are highly suggestive dystopic visions of a not-too-distant future when the human body has suffered a radical mutation in its ecological structure. As such, his works prefigure a culture where the organic architecture sustaining the human sensorium has undergone various degrees of collective bio-technological prosthetic transformations. From the point of view of the cultural complexity of their technological and ecological vision, the best of Gibson's works are therefore positioned at the imaginative threshold of potential post-industrial techno-dystopian cultures." (Tomas, 1989: 113)

Cities of the cyberpunk subgenre, stacked with black market software, hardware and drugs being sold, plus access to illegal surgeries are the illicit and illegal mediums of operation that icontain streets od decaying glory. They generally have a unique structure that combines past and future. Blade Runner (Ridley Scott, 1982), as one of the most important movies of the genre, epitomizes this characteristic:

"The Los Angeles of 2019 is essentially a city of contradiction; high rises, pyramids and glass towers intermingle with revival architecture, historical buildings, and the debris of past urban sprawl. The visual layering of architectural typologies from various cultural pasts creates a post-modern image of a globalized world. " (Abuhela,2005:5)

In this study, Repo! The Genetic Opera, will be analyzed within the context of dystopia, cyberpunk, and its contribution to musics visual and narrative structure.

\section{Analysis}

\subsection{Overture: The Future You See in a Graveyard}

In order to analyze Repo! The Genetic Opera, we have to decipher its opening sequence. Aesthetics of comics are used in the movie to visualize the main story and the characters to support the dystopian atmosphere in the rest of the movie. According to Harvey, comics this can be discussed via four main threads:

"...narrative breakdown -the division of a story into panel units, composition- the arrangement of pictorial elements within a panel, layout- the arrangement of panels on a page and their relative size and shape, and style- the highly individual way an artist handles pen or brush (or draws a face or composes a panel or lays out a page or breaks down a story)...Generally speaking, narrative berakdown is the device by which timing is achieved, by manipulating time, the cartoonist produces dramatic effects of timing by giving varying visual emphasis to different elements of a story or event. The lingo of the cinematographer proves useful here- close-up, medium shot, establishing shot, up-shot, down-shot, tracking, panning, and so forth. But style is another matter. The mark of its marker, its story-telling role is marginal and subtle." (Harvey, 1996: 9,10)

Thus, the movie creates a complete atmosphere within which the viewer is submersed in the sounds and visual sophistry of the event. Music is an integral part of the processing, ensuring an empathetic and emotive connection with the events viewed. Characters' lines are represented in a musical form like all the other musicals. Sharp transitions between the musical genres are intentionally made. Each character's presentation of themselves becomes a code, which creates the behavior pattern and to analyze the purpose of action, there is transition via costume, make up and other auxiliary elements. 
The opening sequence starts with string instruments in a classical form and after the word "Chaos" appears on the screen, the music turns into industrial rock. This transition in the opening sequence shows that the movie will associate rock music with chaos and at the same time it is a sign that, in visual and thematic context, order and disorder, past and future will be melted together. The police sirens, screams and metallic sounds that come from knives which accompany the music, increase the sense of chaos.

Just after the opening scene in comic form, the Grave Robber narration continues. The Grave Robber is integral to the plot and its development informs the audience about the Repo Man and causes Shilo to get involved in the story.

The eerie and cold atmosphere created with the help of blue tint is supported by the lyrics of the song that Grave Robber sings, rhythmic drums, electric guitars, overlapping the image of a woman who tries to escape from the Repo Man, but gets killed eventually. The song is supported by electric guitar and rhythmic drums, which make it sound like a scurvied march. Only the "Repo Man" part is in the opera form and that adds elite and divine meanings to this scary figure of the movie. This point of view refers to the acceptance of desperate people in tragedies, reminds them that our ancient fears never leave us alone and shows that 'evil' always considers itself the ultimate pinnacle of social control, when it comes to getting what it wants.

After that, the name of the movie is represented as a barcode on a product. This design might seem unrelated at first sight, however it reflects the perception of humanity of an evil and strong antagonist. People are as precious as their organs. Placing a barcode on each organ bought by people, indicates the value of the organ and those who purchase it. The most important indicator to this, is that plastic surgery competition which becomes almost a hobby amongst the children of rich antagonist Rotti Largo. The camera flies over to manifest a bleak, dystopian city surrounded by skyscrapers and giant, lighted-up, flying billboards. The camera moves to Rotti Largo's company, GeneCo and approaches to the presentation of Mag's, who is the strongest voice of Genetic Opera and known as the voice of GeneCo, "Farewell Show". The show, which is going to take place in the future, has some traces from the past. Setting, colors and costume are presented to the spectator as a reproduction of the past. After that, the scene ends with the fast moving of the camera down to a burning chimney. Choice of plan sequence can be read as a sign that past and the dystopian future will be melted together in harmony.

The following scene is the scene in which Rotti Largo is introduced. Largo's clothes and his office look nostalgic, designed in a classical manner. Some elements in the following scenes such as the quill pen and pocket-watch, remind us of older times than the actual time of the movie; and opera songs, which sometimes are sung by Largo and are sometimes being played in the background, support that feeling as well. When Rotti is introduced, an opera song is being played in the background, however when the doctor informs Largo about a rapidly spreading disease in his body, Largo gets angry and hits the reports on the table and with the shift from opera to the rock opera piece "Things You See in a Graveyard" one of the two women bodyguards kills the doctor, thus, the severity of the violence is increased via rock music. Even though the bodyguards are female with fishnet stockings and short shorts, they are an antithesis due to their of their role due to their masculine oversized sunglasses which look like masks, their buttoned up shirts, their jackets, their bulk hair and most importantly with their giant guns.

The song "Things You See in a Graveyard" brings together two different genres like opera and rock and also binds GeneCo to the graveyard, also Shilo to Largo. Thus, it melds different characters and places in the same sequence. Themes of the graveyard and death are central to the movie. Repo! The Genetic Opera, is almost a twin to Foucault's "heterotopia" concept, bringing together different times and spaces through music and settings. Foucault's definition of a space of heterotopia requires that the space be unreal and yet exist 
simultaneously in reality. (Dixon, 2004:65) such as the museum, the prison, the hospital, the cemetery (McLeod, 2000:184). Heterotopia is a concept that is always relational; a place can only be "other" to another place (Burrows, 2008:165) Foucault gives the mirror example to explain his notion of heterotopia further:

"...the mirror does exist in reality, where it exerts a sort of counteraction on the position that I occupy. From the standpoint of the mirror I discover my absence from the place where I am since I see myself over there. Starting from this gaze that is, as it were, directed toward me, from the ground of this virtual space that is on the other side of the glass, I come back toward myself; I begin again to direct my eyes toward myself and to reconstitute myself there where I am. The mirror functions as a heterotopia in this respect: it makes this place that I occupy at the moment when I look at myself in the glass at once absolutely real, connected with all the space that surrounds it, and absolutely unreal, since in order to be perceived it has to pass through this virtual point which is over there. " (Foucault, 1986: 24)

Based on Foucault's notions and definitions, it is possible to observe heterotopia in music. The idea that seperate time pieces can be together in same place, could also be applied to musical works. A composition, just like a person who sees their reflection in the mirror, can reproduce time and reality at the age it was created, as well and including reflections of their reality from a point in time that has passed.

\subsection{Act: Phantom of the Past, Assassin of the Opera}

It is considerable that the Grave Robber, even though he is not in the center, links different people. Shilo, who meets the Grave Robber while he was draining Zydrate from dead bodies, draws attention because of the Grave Robber's scream, giving the impression that he wants her to get involved, then gets caught by the police and attempts to throw it off with the excuse of curfew violation, but is then saved by the intervention of the Repo Man. After that, again, with the involvement of Grave Robber, she meets Largo's daughter Amber Sweet; he unites different characters that seem to belong in different times and live in different places, just like a graveyard. On the other hand, he connects the events, functioning as a narrator or Master Puppeteer of events.

Shilo and her father visit Nathan's house, which reminds them of old times even though the movie takes place in the future. This nostalgic mood is spread throughout the overall atmosphere of the movie and emerges as an important code that supports the narrative.

Pam Cook argues in her Screening the Past that nostalgia requires suspension of disbelief to connect with an idealized past.

"The suspension of disbelief is central to this transition, as nostalgia is predicated on a dialectic between longing for something idealized that has been lost, and an acknowledgement that this idealized something can never be retrieved in actuality, and can only be accessed through images. This process can be seen as an activity of 'let's pretend', or role-play: past events can be recreated so that the audience can experience them in the present, imagine what it was like then, and connect emotionally with representations of the past." (Cook, 2005:3)

According to Ono, people need nostalgia because they feel lost and disappointed in the present.

"Today, people are disappointed to learn that scientific and technological advancement does not necessarily fulfill one's life. On the contrary, it can rather alienate and disconnect individuals; unhappy and distraught people are desperate to find a comfortable place in society, 
looking back at the past where once there was a community to which they felt they belonged." (Ono,2008:7)

In this context, fundamental places of the movie such as Shilo's house, Largo's office and the opera building, unite past and future, thus becoming an important example for concept of heterotopia.

The song that Shilo sings, imitating her father, contains humor and satire as we will come accross many times.

\begin{abstract}
"Dystopia appears to be leaving its parent utopia and it is more convenient if we reflect upon this kind of literature as a part of another genre, as a special kind of satire. Dystopias (and from now on I refrain from using the expression negative utopia) are such satires that are displaced, cast in the future or confined in space, and do not limit themselves to the scathing criticism of certain people or phenomena, but scrutinize the workings of society thoroughly, usually putting one element of the problems in the centre, and that element, being magnified, distorts the whole system, or more precisely, shows its distorted nature." (http://seas3.elte.hu/coursematerial/CziganyikZsolt/dystopia0001.pdf)
\end{abstract}

Satire is an element that frequently used in dystopian texts. In Repo! The Genetic Opera, satire increases the power of dystopia, with the support of music.

Nathan forbids Shilo to go outside because of her disease. While she was complaining about this situation, she opens the window and the contrast between the city and the house she lives in (both interior and exterior design) can be seen clearly. The contrast between the warm colors of the house and cool, mostly blue, colors of outside highlight that contradiction even further. Shilo is like a being trapped in a happy reflection of the past and the nostalgia it regurgitates. Albeit how much it looks scary and dark, she prefers freedom and reflects those emotions in the songs that evoke rebellion.

In the scene within which it is revealed that Nathan is the Repo Man, the interior of the house is presented in more detail. The most noticeable objects in the house are the paintings of Nathan's late wife Marni; the paintings project Marni's holograms, make her flow out of the frames, thus causing her appear like a ghost. "The paintings that carry the faces of the past, which are mostly products of English gothic literature, contain important signs that portrays the object relations that belongs to the pre-genital era. These hidden premises transform over time and continue their relationship with the present by being reproduced in the past's common denominator and the paintings" (Demirci,2006:84).

So, the feeling of being trapped in the past is increased. As a Repo Man, Nathan's killing zone is the basement of the house, which can be accessed via a secret passage behind the fireplace; this scene, breaks the illusion that the house is beautiful and warm, and (safety from) nostalgia falls apart. While the fireplace slides to one-side and reveals a secret passage; noticing that the fire is only an image on the television screen emphasizes this fact. The rock song "Legal Assassin" sung by Nathan reflects his dark side and supports the contrast between the killing floor in the basement and the warm atmosphere of the house as a whole. While Nathan pulls the fireplace toward himself, he says "I am only living out a lie!" which is the last sentence of the first part of the song, before it changes and reveals Nathan's dark side. This mise en scene deconstructs the illusion in the musical context also.

The basement, which is frequently used in horror movies as a place for the uncanny, a place to hide what needs to be hidden, can be read as a spatial expression of subconscious as defined by Freud, or 
unconscious as defined by Jung. According to Freud, the memories that we want to suppress or forget, or the motives such as violence or sex, which he defines as id, belong in the subconscious. Id is chaos according to Freud, and the movie starts with the word, "chaos". It "knows no values, no good and evil, no morality." (https://www.marxists.org/reference/subject/philosophy/works/at/freud2.htm). Jung defines these impulses with the shadow self.

"The darkness which clings to every personality is the door into the unconscious and the gateway of dreams, from which those two twilight figures, the shadow and the anima, step into our nightly visions or, remaining invisible, take possession of our ego-consciousness. A man who is possessed by his shadow is always standing in his own light and falling into his own traps. Whenever possible, he prefers to make an unfavorable impression on others. In the long run luck is always against him, because he is living below his own level and at best only attains what does not suit him." (Jung, 2001:66).

Repo Man can be seen as the shadow-self of Nathan.

\subsection{Interlude: Zydrate, Anatomy of a Dystopian Future}

The following scene starts with the song "Lungs and Livers" and continues with "Mark it Up". The visuals which accompany "Mark it Up" contain violence as a contrast to the humor in the song. This scene, which displays organs being labeled, is also one where the siblings are arguing about who will take over GeneCo. While the characteristics of the siblings are presented in an entertaining way, it is also a telling dialectic on what bigbusiness is all about.

"Megacorporation is a term popularized by William Gibson derived from the combination of the prefix Mega- with the word corporation. It has become a term popularly used in cyberpunk literature. It refers to a fictional corporation that is a massive conglomerate, holding monopolistic or near-monopolistic control over multiple markets (thus exhibiting both a horizontal and a vertical monopoly). Megacorps are so powerful that they can ignore the law, possess their own heavily-armed (often military-sized) private armies, hold 'sovereign' territory, and possibly even act as outright governments. They often exercise a large degree of control over their employees, taking the idea of 'corporate culture' to an extreme. Such organizations are a staple of science fiction long predating cyberpunk, appearing in the works of writers such as Philip K. Dick (Do Androids Dream of Electric Sheep?), Thea Von Harbou (Metropolis), Darren Smith and Terrance Zdunich (Repo! The Genetic Opera), Robert A. Heinlein (Citizen of the Galaxy), Robert Asprin (The Cold cash War) and Andre Norton (the Solar Queen novels)." (Wikipedians, n.d. :163.)

In the next scene, Largo tells about his past to the audience. Grave Robber, who is the narrator, frequently breaks the fourth fall, which Bertolt Brecht also called the alienation effect:

"The "alienation effect" has been used in Germany in plays of a non-Aristotelian kind, that is, in plays which are not based on empathy (einfuehlung). I refer to various attempts to act in such a manner that the spectator is prevented from feeling his way into the characters. Acceptance or rejection of the characters' words is thus placed in the conscious realm, not, as hitherto, in the spectator's subconscious."(Brecht, 1961:130).

Even though the narration is constantly interrupted by the songs which switch from one genre to another and the characters who talk to the audience which breaks the fourth wall, this situation does not end 
with the audience's alienation. On the contrary, the audience anticipates and prepares for the next scene/performance or gets dragged into the movie via participating with plots of the villain, which are unknown to the other characters.

Min Tian, in his paper about "On Chinese Acting" which Brecht wrote about and examined the alienation effect, mentions about a similar situation in Chinese theatre.

"...absence of the "fourth wall" does not necessarily result in the A-effect. In fact, in the Chinese theatre the audience is not alienated from what is going on upon the stage but, rather, is invited into the poetic atmosphere and imagination created by the actor's performance, which synthesizes poetry, singing, and dancing. In addition, as a result of the absence of the "fourth wall", the audience has no illusion of being the unseen spectator. However, this does not result in the elimination of the stage illusion created by the actor through his performance. Here, of course, the illusion is not the naturalistic one to which both the Brechtian epic theatre and the Chinese theatre are opposed; it is that kind of illusion primarily of poetic and emotional atmosphere and artistic realm (yijing) which is based, not on objective verisimilitude in physical form, but on subjective likeness in emotion and spirit (shensi). This kind of illusion works on the imagination and emotion of the spectator who relishes his aesthetic and empathetic pleasures and sympathies while enjoying the performance. It has nothing in common with Brechtian Aeffect." (Tian, 1997:205)

In the scene that Largo explains how he tricked Nathan, electric guitars are playing in the background. While he was talking to Shilo to trick her into his car, he starts to sing in classic opera form. Opera genre, is being represented as a sign of lies, corruption and evil, in an unorthodox way, and it evokes the feeling that the evil may represent itself in the disguise of supreme art.

In another scene, Nathan starts to sing "Thankless Job". This scene contains joyful melodies similar to "Mark it Up", even though it is one of the most violent scenes in the entire movie. However, the function of this choice is not satire or humor this time, but to emphasize Nathan's split personality which drives him insane, ergo cheerful melodies and wisecracking lyrics, create a contrast with bloody images, thus an increase in the power of Nathan's horrifying state. When Nathan finishes the song, he looks at the man in confusion who rips his organs, as he wasn't the man who did it, pulls himself together, washes his bloody clothes and cleans the mess of the murder.

After that, Mag's advertisement about GeneCo products starts. Mag, speaking in front of a red curtain at the opera building as always, camera tracks out and reveals the dystopian city which is surrounded by advertisements and billboards, breaking the illusion that the advertisements create, and takes the audience to the carnival. The intertwinement of GeneCo advertisements' sounds and carnival images may be perceived as GeneCo itself as a deceiving carnival. Largo's children having a short argument by singing a song similar to "Mark it Up" in the carnival, then Largo steps in, and introduces Shilo to Mag via singing an opera song. Mag's story is told to the audience. The opera song which Mag and Largo sing together also serves as a medium to hide their real intentions for Largo. The scene where the Grave Robber, Amber Sweet and Shilo meet is one of the scenes that sexuality, violence and fetishism are centralized. Grave Robber and Amber Sweet are singing "Zydrate Anatomy". The song is about Amber Sweet who is addicted to surgery and Zydrate, which is a drug that is being injected to one's body before the surgery. Zydrate has similar effects with soma from Brave New World by Aldous Huxley. Zydrate, besides its painkiller strength, is addictive. 
Amber Sweet and her two bodyguards, come to a street where one of the themes is related to a cyberpunk subgenre who provide illegal surgery operations are made. The bodyguards and Amber Sweet wearing, tight, provocative leather clothes that expose their bodies. Shots during Zydrate injection and surgery, intervening plans and choreography remind us of sexual intercourse, and it is noticeable that Amber Sweet is having sexual pleasure from the surgery. Lyrics that sang whispering strengthen the sexual codes in the scene.

According to Baudrillard, "current structures of production/consumption induce in the subject a dual practice, linked to a split (but profoundly interdependent) representation of his/her own body: the representation of the body as capital and as fetish (or consumer object)." (Baudrillard, 1998: 129). "In the consumer package, there is one object finer, more precious and more dazzling than any other - and even more laden with connotations than the automobile, in spite of the fact that that encapsulates them all. That object is the BODY." (Baudrillard, 1998: 129). Amber Sweet uses her body as a consumption object by both being exhibitionist, surgeon and beauty addict, and at the same time she becomes the object of desire for the audience. On the other hand the scene where she asks for money from her father, the shots in front of the mirror are signs of how much she hates the way she looks and her will to change it. Amber Sweet's body, which keeps decaying over time, is the biggest object of desire and consumption for herself. Pure vanity.

Nathan is summoned by Largo, at the same time, Shilo comes home secretly. Tension and dramatic narration between them is supported by string instruments and piano, similar to contribution of music to narrative structure in silent movies. The scene that Largo tries to convince Nathan to kill Mag, a song called Night Surgeon begins. The song is in rock opera form and it comes and goes between rock and opera genres just like Nathan, who comes and goes between Repo Man and Nathan personas.

When Meg meets Shilo, we see one of the most important elements of cyberpunk: augmentation. Meg's eyes, which are GeneCo products, not only let her see, but also projects three-dimensional holograms of the saved memories. This scene is one of the few scenes where the high-tech is used. This scene fuses the technology of Meg's eyes with the nostalgic, retro structure of the house and clothes. The music supports this retro-futuristic mise en scene by fusing together techno, rock and opera.

The song "Seventeen" that Shilo sings which is a rebellious act against her father, is different from the other songs in the movie, being similar to the songs of rock bands which target teenagers. The most noticeable characteristic of the scene is, as soon as Shilo starts to sing, the light, the costume and setting begin to change as well. By doing so the scene reflects Shilo's imagination. The only scene, which there is no continuity of space, is this scene. "Loud and cheerful musical interludes are there as an ironic "slowdown" to provoke desire as if they are under the influence of a blinding spell." (Biro, 2011: 95)

"In most cases, the progress of a character, deviates from the original, "standard" path and slides into foreign lands by a new, perceivable factor that rises to surface (like an object, unexpected emergence of a person, a change in natural environment. Or while not being completely immune from these factors, main character gets forced to introvert." (Biro, 2011:90).

\subsection{The Final Curtain: We are Betrayed at the Opera Tonight!}

Shilo, returns to Largo's call and decides to go to the opera. Nathan finds out about Largo's call and goes home, however cannot find Shilo and says, "Tonight, we are betrayed!" (which is also the name of the song). This sentence he said by changing his voice is important because of usage of the first person plural, emphasizing Nathan's split personality which manifests itself in an uncontrollable manner. Scene continues constructing upon dualities and contrasts. Nathan the father sings with a tender, dramatic voice, who worries about her daughter, while Nathan the Repo Man, growls with a creepy voice. The rock opera song named "At the Opera 
Tonight" brings together all the singing characters. Even if they are at different places, they are together as a concept and they complete each other. Nathan prepares to get revenge and wears his Repo Man clothes, while Mag walks in the graveyard, her clothes and ghostly white skin add a gothic atmosphere to the scene. Shilo heads to the opera building while Largo is making preparations for him and Nathan there. Even though they are all in different places, the song they sing completes each other. Then the Grave Robber, breaks the fourth wall again and preps the audience for the next scene.

After protecting the city, which is noticeable for its futuristic elements, by high angle wide shots, the people in retro costumes who are waiting for the show and the classical interior of the building are shown. That creates a contrast between the city and the opera building. As a piano piece is being played in the background while the spectators watch the stage with lorgnettes and Mag prepares for her performance. After the curtains are opened, a rock band wearing grotesque masks appears on stage and start to play a song called, "We Started This Op'raSh*t", and with the female dancers, elderly DJ and singer dressed like a conductor, the entire scene becomes grotesque. Because of the dancers' choreography, the scene also has certain amount of eroticism. The spectators are expressing their satisfaction from using GeneCo products turns the scene to an advertisement and makes it even more awkward. Rotti Largo strengthens his pompous entrance by singing opera. In the city, giant sized billboards of Mag's latest show are placed everywhere. Opera form is transformed into a product of a mass culture, an instrument of parade and hysteria. The people, who cannot afford to go to an opera, have to watch it from the big screen or the televisions on the streets.

Shilo is taken to a room at the opera building from where a movie prepared by Largo is projected through a projector to a screen and his voice fills the room. The movie, which tells of the coming of the Repo Man coming to kill Shilo. Largo tries to stop him, this portion encapsulated in a simulated black and white silent movie style and full of scratches, has a crackling sound. The movie that has been edited with footage of Shilo and the Repo Man, reminds us of a propaganda movie with the short warning captions such as "BE ON GUARD!" and "HE IS COMING". In the final shot everything is left in the dark except the face of Shilo, illuminated by the flashlight in her hand, gives the impression of Shilo's isolation from the environment that surrounds her and expected impact of propaganda on Shilo is presented dramatically. Using silent movie aesthetics implies that past and nostalgia has its own magic and people can easily be moved to reflections of nostalgic binds with the past, and get lost in the present. Possession of Shilo's and the Repo Man's footage turns Largo to "Big Brother", who sees everything.

Before Mag, Amber Sweet appears on the stage singing, her face drops as the audience heckle her down. This scene emphasizes that the spectator sees her as an object of fleeting desire too that unless remaining perfect is suspect to attack. The place where the perfect bodies are served, which people go to get satisfied are almost all turned into a freak show. Amber Sweet runs out of the scene and Mag is announced.

Mag is dragged across the stage with ropes and she starts to sing the Italian dirge "Chromoggia". For the first time in the movie, via both the stage design and the song, the audience is watching a real opera will witness a real tragedy. All the components of opera will reveal the tragic destiny of actors immemorial.

Mag finishes her song by gouging her eye out for final theatrical effect. Largo cuts the ropes which were keeping Mag in the air and lets her fall down on the iron fence décor and die. The spectators both at the opera building and outside are shocked and sad. The curtain closes and Largo tells people that what they watched was only a spectacle and he continues by saying that in the next performance they will observe the show of a sick girl and her imperious father. The conclusion of the movie is in the same scene and takes place also as a spectacle. Shilo learns the truth about herself and her father. Largo kills Nathan and then dies because of his disease. Shilo leaves the opera as a free individual. This dramatic sequence is like a movie within a movie. The 
audience get excited from observing the peeling away of the onion, layer-by-layer, intricacy by intricacy all leading to a crescendo; as it is for the average opera viewer. At the same time, because everything takes place on an operatic stage, everything seems fake and exaggerated. Like Aristo stated, "there are things that we find painful to look at in real life - misshapen animals, for example, or corpses - and yet we take pleasure in looking at the most accurate images of them." (Aristo, 1997:57). Ergo, what happened, will be erased very quickly, especially from the minds of spectators at the opera; at least it is not going to be remembered as real. In fact, when Grave Robber is telling the audience what happened, we get to know that GeneCo is shared between Largo's children and the megacorporation remains in service. The Grave Robber is glad because he will keep profiting from the black market. Nothing has changed. The movie ends using the aesthetics of comics, as it does in the beginning, informing the audience about the future of GeneCo, with it coming under the management of Amber Sweet.

\section{Results}

Music, has been used to support narrative structure since the time of silent movies and considered as one of the codes of communication within the environs of cinema by Christian Metz, as besides adding depth to narrative, giving audience an immersive experience, making identification stronger, associating specific themes with emotions through leitmotifs, plays a key role in musical genres rather than being merely a supportive element. A strong symbiosis of music and cinema via a union between the lines, dynamics between characters and visual structures that are presented with a musical backdrop enrich what cinema is. Regarding science fiction movies, more specifically diystopian science fiction movies, sound design and music contains another meaning, since they need to transfer the feeling of despair and horror of the world they create to the audience, make them feel like they are part of it.

Dystopian narratives and their visual representations are often used in science fiction movies as they offer an imagery about one of the most interested and feared subjects of humanity: the future. While reflection of future manifests itself in the form of electronic music, movies that tell epic stories in space such as 2001: A Space Oddysey and Star Wars, may prefer epic orchestral music or opera; yet in the movie The Fifth Element, which belongs to space opera subgenre, an alien named Diva Plavaguna supports the narrative in both musical and visual context by singing an opera song on stage.

Rock music, which is often associated with rebellion, violence, sex and drugs, may be represented as the music of people who try to represent revolution and fight against mega-corporations; such as modern day hackers who are placed in the role of freedom fighters, or criminals in the streets who set up their own rules.

Within this context, Repo! The Genetic Opera, combines the characteristics of dystopian science fiction films, musicals and the language of comics as a unique medium for storytelling. It is possible to say that film could be considered as an example of a hybrid combination of different mediums as well as different genres, since it melts music genres like rock, rock opera, techno; and mediums like cinema and comics. The scenes, working along with the mise-en-scene, bring together the past, the present and the future, and fuse them into one reality. Some visual elements associated with the past such as clothes, accessories, furniture, and the future projects of the company GeneCo, coexists at the same time and place together. The characters, the visuals and the music in the film are undertaking the task of bringing different times, places, genres and mediums together. These aspects also emphasize the heterotopic atmosphere of the film.

The film contains different stories of different characters, but all the stories are represented with the same narrative form. The first medium that the audience encounters is comics, with instrumental music in the background, within which the characters' past is introduced to the spectator, then images of the past have 
been displayed from the characters' point of view with rock opera in the background. Therefore it can be put forward that the music is binding the past with the present.

The irony and satire that can be found in some scenes as mentioned previously, is by taking an eagleeyed look at the macro level; it can be seen that the whole film is an ironic representation of the present time. Events in the dystopian future of the movie are actually criticisms of our present. Presenting Rotti as the architect of corruption even though he sings only opera and tries to identify himself as elite, can be considered as a systematic criticism depicted in such a musical manner.

The different genres and mediums in the film work together compatibly. Even if they don't belong together, music unifies them; just like the characters in the film. Their organs work together compatibly; even though some of them don't potentially belong, they are all hosts to that identity which is in toto a single representation of entertainment.

\section{References}

Abuhela, I., 2005, Significance of Future Architecture in Science Fiction Films, First Architecture and Urban Planning Conference, Cairo

Aristotle, 1997, Poetics, translated by George Whalley, McGill-Queen's University Press, London

Barrios R. 1995, A Song in the Dark: The Birth of the Musical Film, Oxford University Press, New York

Baudrillard, J., 1998, The Consumer Society:Myths and Structures,Sage Publications, London

Biro, Yvette, 2011, Sinemada Zaman/ Ritmik Tasarım ;Türbülans ve Akış, translated by Anıl Ceren Altunkanat, Doruk Yayımcilık, ìstanbul

Burrows, V., 2008, The Heterotopic Spaces of Postcolonial Trauma in Michael Ondaatje's Anil's Ghost, Studies in the Novel, Volume 40, Numers 1\&2, John Hopkins University Press, pp.161-177

Brecht, B., 1961, On Chinese Acting, The Tulane Drama Review, Vol. 6, no. 1, The MIT Press, pp. 130-136

Cavallaro, D., 2000, Cyberpunk and Cyberculture: Science Fiction and the Work of William Gibson, The Athlone Press, London

Citron M. J., 2010, Opera on Screen, Yale University Press, U.S.A.

Cook, P.,2005, Screening the Past: Mermory and Nostalgia in Cinema, Routledge, London and New York

Çedikçi T., 2008, "Eğlence Sektörünün Ülke Ekonomisindeki Yeri: Bir Uygulama Örneği, Müzikaller", ìstanbul Kültür Üniversitesi, Institute of SocialSciences, Master Thesis

Demirci, T.T., 2006, Korku Sinemasının Psikanalizi, Es Yayınları, i̇stanbul

Dixon, S., 2004, Heterotopic Spaces of Childhood, Master Thesis in The Department of Sociology and Anthropology, Concordia University, Canada

Elicker M., 2002, Rock Opera - Opera on the Rocks?,Word\& Music Studies, Vol.4, pp. 299-314.

Fisher B. D., 2005, A History of Opera: Milstones and Metamorphoses, Opera Journals Publishing, Florida.

Foucault, M.,1986, Of Other Spaces, Diacritics, translated by Jay Miskowiec, Vol. 16, No. 1, The John Hopkins University Press, pp. 22-27

Grossman A. L., 2012, "Identity Unknown: A Study and Performance of Interactive Rock Opera", Ohio University, Master Thesis

Harris, J, 2003, The Future We Love to Hate: Technology in Sci-Fi, Acoustic, Speech, and Signal Processing Newsletter, IEEE, Vol. 44, Issue 4, pp 77-83

Harvey, R.C.,1996, The Art of the Comic Book: An Aesthetic History, University Press of Mississippi, Jackson

ilyasoğlu E., 2009, Zaman İ̧̧inde Müzik, Remzi Kitabevi, İstanbul

Jung, C.G.,2001, Four Archetypes, Routledge, London and New York

Lena J. C.,Peterson R. A., 2008, Classification as Culture: Types and Trajectories of Music Genres, American Sociological Rewiev, Vol.73, pp. 697-718. 
Mahida, C.A. , 2011,Dystopian Future in Contemporary Science Fiction, Golden Research Thoughts, Vol. 1, Issue 1, pp. $1-4$

McClellan R., 2000, The Healing Forces of Music: History, Theory and Practice, iUniverse.com, U.S.A.

McLeod, Mary, 2000, "Everyday and Other Spaces." Gender Space Architecture: An Interdisciplinary Introduction. Ed. Jane Rendell, Barbara Penner, and Ian Borden, Routledge, 2000. pp. 182-202, New York

Mundy J., 2006, Television, The Pop Industry and The Hollywood Musical, içinde: Conrich I., Tincknell E. (eds), Film's Musical Moments, Edinburgh University Press, Edinburgh, pp. 42-56

Nassour E.,Broderick R., 1973, Rock Opera: The Creation of Jesus Christ Superstar, from Record Album to Broadway Show and Motion Picture, HawthorneBooks, U.S.A.

Ono, Y., 2008, Nostalgia and Futurism in Contemporary Japanese Sci-FiAnimation, Asiascape.net Occasional Paper Series, Issue 3,Leiden University, pp. 1-9

Parkinson D., 2007, The Rough Guide to Film Musicals, Rough Guides, U.S.A.

Reilly, P., 1989, Nineteen Eighty Four- Past, Present, and Future, Twayne Publishers, Boston

Say A., 1997, Müzik Tarihi, Müzik Ansiklopedisi Yayınları, Ankara

Sonneck O. G., 1913, "Dafne", the First Opera. A Chronological Study, Sammelbände der Internationalen Musikgesellschaft, pp. 102-110

Storey J., 2002, “ExpectingRain": Opera as Popular Culture?, içinde: Collins J. (ed), High-Pop: Making Cultureinto Popular Entertainment, Blackwell Publishing, U.S.A. pp. 32-56

Tambling J., 1987, Opera, Ideology, and Film, Manchester University Press, U.K.

Tian, M.,1997, "Alienation-Effect" for Whom? Brecht's (Mis)interpretation of the Classical Chinese Theatre, Asian Theatre Journal, Vol. 14, No. 2, University of Hawai'i Press, pp. 200-222

Tomas, D., 1989, "The Technophilic Body", New Formations, Sayı 8, Londra, Lawrence and Wishart Publishing, pp.113-139, Londra

Whittington, W., 2007, Sound Design and Science Fiction, University of Texas Press, Austin

Wikipedians, n.d. ,William Gibson, PediaPress

Internet References

Cziganyik, Zsolt, Satire and Dystopia: TwoGenres?,http://seas3.elte.hu/coursematerial/CziganyikZsolt/dystopia0001.pdf ， accessed 14.03.2016

Freud, S.,from LECTURE XXXI (1932) TheAnatomy of the Menta IPersonality, https://www.marxists.org/reference/subject/philosophy/works/at/freud2.htm, accessed 10.04.2016 